\title{
Trend on TEFL Research: A Study in English Education Department of IAIN Bukittinggi in the Period of 2015 to 2017
}

\author{
Agustia Fadhila ${ }^{1 *}$ and Irvonny Gustira ${ }^{2}$ \\ ${ }^{12}$ English Department, FBS Universitas Negeri Padang, Padang, Sumatra Barat 25131, Indonesia \\ *Corresponding author email: gustirairvonny@gmail.com
}

\begin{abstract}
This research was conducted due to the problems that were faced by the students of English Education Department of IAIN Bukittinggi. The problem is that students tended to use the same topic on their research. Students did not explore creatively the scope of TEFL, so that they did the same research topic. The design of this research was descriptive quantitative research. The data was gotten through documentation. Sample of this research were 169 thesis abstracts from total population were 182 thesis abstracts. The samples were taken using purposive sampling technique. Researcher served the data into table of the trend on TEFL research. The technique of data analysis was through content analysis. Based on the findings of the research, it was found that the result showed the trend on TEFL research. The trend was then identified into three categories: research topic, target language skill and research method. The findings showed that teaching style or strategy was balance with planning and course design as the trend on research topic $(24.85 \%)$. Writing was the trend on target language skill (19.52\%). Descriptive quantitative was the trend of research method $(42.01 \%)$.
\end{abstract}

Keywords: Research Trend, Thesis, TEFL

\section{INTRODUCTION}

Research is an important scientific activity in education. Research is a process of solving the problem using scientific approach and scientific method in formulating or explaining the problems. Research is essentially an attempt to discover, develop, and test the truth of-knowledge systematically and rationally. Solution for educational problems can be found out through research.

Educational research is the scientific field of study that study education and learning processes. Educational research also examines the human attributes, interactions, organizations, and institutions that shape educational outcome. It is a systematic process of acquiring knowledge and problem solving through scientific method.

One of the efforts to improve the quality of English education graduates is through conducting research in English education department. Besides, the result of the research must be able to answer the challenge and develop new theories in English language teaching. Therefore, all students in English education program should be led to do the research in term of teaching English as foreign language.
Research in teaching English as foreign language has a very important role to improve the teaching and learning process. For teacher, the result can be used to make decisions in the classroom, and give variation in teaching. For example, teacher can decide what techniques are the most suitable to use in particular classroom. Briefly, it helps the teachers to be successful in teaching students.

Research in English language teaching has a large scope. Teaching English as foreign language can be grouped into several categories such as learning, design of teaching, objective of the method, syllabus, types of learning and teaching activities. Besides, teacher and students roles are also a part of teaching and learning.

The large scope of teaching English has potential to create some topics research. It is concerning with the implementation of teaching strategies in teaching of English language skill and component. The topic includes, story pyramid, talking chip, mind map, dictoglos, think aloud strategy, and so on [1]. Most of students has tendency to choose the topic of research based on previous studies. Consequently not all problems in teaching English can find the solutions. The task of the students as a researcher is to conduct research in various scope of teaching English. The 
variation in student research depends on their knowledge of the scope of teaching. Therefore, teaching English as foreign language research should be able to covers the whole scope of teaching English as foreign language.

\section{REVIEW OF RELATED LITERATURE}

2.1. The Nature of Teaching English as Foreign Language

a. Definition of Teaching English as Foreign Language

Teaching English as foreign language does not aim to master the Language, however it is taught as a curriculum in education institution. They are forced to use as communication in daily life. The purpose of teaching English in classroom is just to transfer language skill to students.

In EFL context, learners study English for different purposes such as passing the examination, career development, pursuing their education, etc. In Indonesia, English is a compulsory subject in senior and junior for high schools. Teaching English as foreign language is the teaching of English to people whose first language is not English, especially people from a country where English is not spoken.

English foreign language is used in contexts where English is neither widely used for communication, nor used as the medium of instruction [1]. It means that English is used as an official language. So, teaching English as foreign language is focused on the purposes or studies of English by teachers and English language learners with a different mother tongue.

\section{b. The Scope of Teaching English as Foreign Language}

Scope of teaching English as foreign language contains all areas of English language studies including language skills, language components, and the factors affecting the teaching or learning of English as a foreign language. It describes that the field of teaching English as foreign language also discusses about lesson plan and assessment. It involves the way teacher transfers the English lesson to the students. There are also some categories of teaching English as foreign languages, namely age, psychological, sociocultural, and linguistics factors [2]

\subsection{The Nature of Educational Research}

Educational research is the scientific field of study that examines education and learning processes and the human attributes, interactions, organizations, and institutions that shape educational outcomes. Educational research is the application of the scientific approach to the study of educational problems [3]. It means that researcher conducts research to find a solution to some problem or to gain insight into an issue that the researcher does not understand.

Furthermore, educational research can be defined as a cyclical process of steps that typically begins with identifying a research problem or issue of study [4]. It then involves reviewing the literature, specifying a purpose for the study, collecting and analyzing data, and forming an interpretation of information. This process culminates in a report, disseminated to audiences that is evaluated and used in the educational community. It can be concluded that educational research is a systematic process starting from formulating the problem.

\subsection{Trend on TEFL Research}

We use trend to describe some tendency to know a pattern of gradual change in a conation, output, or process, or an average or general tendency of a series of data points to move in a certain direction over time, represented by a line or curve on a graph in research. Trend or prediction studies have an obvious importance to educational administrators or planners [5]. Essentially, the trend study examines recorded data to establish patterns of change that have already occurred in order to predict what will be likely to occur in the future. In trend studies two or more cross-sectional studies are undertaken with identical age groups at more than one point in time in order to make comparisons over time.

\section{a. The Trend of Topic}

Some trends of topic are followed:

1. Pedagogy

2. English instruction in the levels of Kindergarten, Elementary, and Secondary;

3. Curriculum and its implementation, Strategies of Native Speaker in teaching English,

4. Item test analysis

5. Developing instructional materials and media National Test

6. Learner and Teacher's Talk,

7. Translation

8. English instructional problems.

9. Students' learning styles.

\section{b. $\quad$ The Trend of Research method}

A research about research trend of EFL students in English education program was conducted from 2005 to 2015 [6]. The result revealed that there were six important points. Firstly, TEFL is the trending research topic among English education students' theses within the past eleven years. Secondly, $53.11 \%$ theses could not successfully demonstrate niche/gap. Next, trend of formulating research objectives was appropriate with 
the research title. Then, trend in the students' theses was concluding the related literature and previous studies. Descriptive qualitative was the most popular research method implemented by the students within the last eleven years.

Moreover, the current research trends of English education in domestic and international journals were conducted from 2011 to 2013 [7]. The result revealed that university students have participated most in Articles in domestic journal (English Teaching) and international journal (Tesol Quartely), and quantitative and qualitative research methods were well balanced. In terms of target language skill, writing has been studied most in English Teaching and speaking in Tesol Quartely, andas for research topics, articles based on socio-cultural factors have been published most in TQ and articles based on classrooms pedagogy in ET.

From the explanation of related to the previous researches, the researcher is interested to study trend on TEFL Research in English Education Department of IAIN Bukittinggi periode 2015 to 2017". Since this research is quite different with the others as mentioned above, the result of this research is expected to give new perception toward trend on TEFL research and how far the research touches the various scope English teaching.

\section{RESEARCH METHOD}

\section{Design of the Research}

Based on the purpose of the research and the nature of the problem, this research used descriptive research design. The purpose of the research was to describe the phenomenon existing in field in order to get the information. Descriptive quantitative research describes behaviors, outcomes, scores, by using statistic such as frequencies, percentages, and other descriptive statistic [4]. It means that this research will make an attempt to define the percentages of each trend on TEFL research. This research also used content analysis because content analysis is a method use in analyzing document. It means that it analyzes human written contents of a communication such as thesis, textbook, essay, newspaper, song, poem, and article.

\section{Population and Sample}

The population of this research was the students' entire thesis written in the last three years of English Education Department of IAIN of Bukittinggi academic years 2015-2017 consists of 182 students' thesis abstract.
Table 1, population of the TEFL students' thesis written within 2015-2017 (Source: library of IAIN Bukittinggi)

\begin{tabular}{|l|l|l|}
\hline No & Year & Population \\
\hline 1 & 2015 & 47 thesis \\
\hline 2 & 2016 & 43 thesis \\
\hline 3 & 2017 & 92 thesis \\
\hline \multicolumn{2}{|l|}{ Total } & 182 thesis \\
\hline
\end{tabular}

Sample was a part of the population which is the representative of the population. Sample is one of that representatives of the population from it was selected [8]. So it can be conclude that sample is the part of population which is going to be researched by the researcher in finding certain data.

Purposive sample technique was used to make the data more accurate. Purposive sampling technique is a technique that is used by researcher if that researcher has some certain consideration to determine the samples [9]. The sample of this research was 169 thesis abstracts about TEFL from 182 the total of population.

\section{Instrumentation}

In this research the researcher used documentation as instrument. The documentation as the process of searching the data about research variables from notes, transcripts, books, magazines, inscriptions, logger, and agenda [9] .The instrumentation used in this research was thesis of students in English Department written during $2015-2017$.

To collect the data researcher went to the library, then classified the thesis from 2015 until 2017. After that the researcher identified the thesis related to the TEFL research. The researcher used a kind of formal documentation In this research, researcher analyzed the data by using content analysis. These are the steps in analyzing data;

a. Making categorization: category for research topic, target language skill and research method.

b. Collecting the thesis abstract and catalogue of thesis tittle.

c. Identifying the students' thesis abstract based on categories using tally

d. Accumulating the result of identification categories into table.

e. Finding out of the percentage of each categories. By using the formula:

$$
\begin{aligned}
& \mathrm{P}=\frac{F}{N} \mathrm{X} 100 \\
& \text { Where } \mathrm{P}=\text { Parentage } \\
& \mathrm{F}=\text { Frequency } \\
& \mathrm{N}=\text { Total Subject }
\end{aligned}
$$

f. Making table frequency and diagram.

g. Then explaining of each item based on table. 


\section{FINDINGS AND DISCUSSION}

The findings of this research are divided into three parts based on the research questions on the TEFL students' research trends during the past three years (2015-2017) namely trends on research topics, target language skill, and research methods.

Table 2. Research Category

\begin{tabular}{|l|l|l|l|}
\hline No & Research Topic & $\begin{array}{l}\text { Target } \\
\text { Language } \\
\text { Skill }\end{array}$ & $\begin{array}{l}\text { Research } \\
\text { Method }\end{array}$ \\
\hline 1 & Approach/Methodology & Listening & $\begin{array}{l}\text { Descriptive } \\
\text { Qualitative }\end{array}$ \\
\hline 2 & Teaching Technique & Speaking & $\begin{array}{l}\text { Descriptive } \\
\text { Quantitative }\end{array}$ \\
\hline 3 & Style And Strategy & Reading & Experiment \\
\hline 4 & CALL/Multimedia & Writing & Correlation \\
\hline 5 & $\begin{array}{l}\text { Classroom } \\
\text { Management }\end{array}$ & Grammar & Comparative \\
\hline 6 & $\begin{array}{l}\text { Planning And Course } \\
\text { Design }\end{array}$ & Vocabulary & R\&D \\
\hline 7 & Personality Factor & Pronunciation & $\begin{array}{l}\text { Action } \\
\text { Research }\end{array}$ \\
\hline 8 & Linguistic Factor & $\begin{array}{l}\text { Integrated } \\
\text { Skill }\end{array}$ & $\begin{array}{l}\text { Content } \\
\text { Analysis }\end{array}$ \\
\hline
\end{tabular}

a. The trend of TEFL research in term of topic among the theses of students in English Educational Program periode 2015 to 2017.

The result of data analysis showed that style strategies and planning and course design were the most popular $(24.85 \%)$ research topics among others. The table below shows the percentage of the trend on research topic in the year of 2015:

Table 3. Trend on research topic in the year of 2015

\begin{tabular}{|c|c|c|c|c|}
\hline No & & Tallies & Frequency & percentage \\
\hline 1 & Approach or Methodology & WI & 5 & $10.86 \%$ \\
\hline 2 & Teaching Technique & W1 & 5 & $10.86 \%$ \\
\hline 3 & Style and Strategy & HW $\#|+|||$ & 13 & $28.26 \%$ \\
\hline 4 & CALL/Multimedia & |III| & 4 & $8.69 \%$ \\
\hline 5 & Classroom management & |II & 3 & $6.52 \%$ \\
\hline 6 & Planning and course design & HII III & 8 & $17.39 \%$ \\
\hline 7 & Personality factor & ||| & 3 & $6.52 \%$ \\
\hline 8 & Linguistic factor & WI & 5 & $10.86 \%$ \\
\hline & \multicolumn{2}{|l|}{ TOTAL } & 46 & $100 \%$ \\
\hline
\end{tabular}

Based on Table, the highest frequency for topic that was chosen was style and strategies $(28.26 \%)$, the second highest was planning and course design (29.8\%), and the third was approach or methodology. Teaching technique and linguistic factor were balance (10.86), the fourth was CALL/Multimedia (8.69), and the lowest research topic was classroom management and personality factor (6.52). The percentage was gotten by finding the average of each topic chosen by the students.

Table 4. Trend on research topic in 2016

\begin{tabular}{|c|c|c|c|c|}
\hline No & & Tallies & Frequency & Percentage \\
\hline 1 & Approach or Methodology & || $\mid$ & 3 & $7.89 \%$ \\
\hline 2 & Teaching Technique & |II| & 4 & $10.52 \%$ \\
\hline 3 & Style and Strategy & 曲 |||| & 9 & $23.68 \%$ \\
\hline 4 & CALL/Multimedia & \|\|$\|$ & 4 & $10.52 \%$ \\
\hline 5 & Classroom management & $\mid\|\|$ & 4 & $10.52 \%$ \\
\hline 6 & Planning and course design & 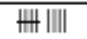 & 9 & $23.68 \%$ \\
\hline 7 & Personality factor & I & 1 & $2.63 \%$ \\
\hline 8 & Linguistic factor & $\mid\|\|$ & 4 & $10.52 \%$ \\
\hline & \multicolumn{2}{|l|}{ TOTAL } & 38 & \\
\hline
\end{tabular}

Table 4 shows the total percentage of the trend on TEFL research in term on topic chosen by students in 2016. The highest percentage was style or strategy (23.68\%), and the second highest was teaching technique, CALL/Multimedia, classroom management, linguistic factor $(10.52 \%)$. Next, the third one was approach and method (7.89), and the lowest one was personality factor $(2.63 \%)$. The percentage was gotten by finding the average of each topic chosen by the students.

Table 5. Trends on research topic in 2017

\begin{tabular}{|c|c|c|c|c|}
\hline No & Research topic & Tallies & Frequency & Percentage \\
\hline 1 & Approach or Methodology & 冊 |||| & 9 & $10.58 \%$ \\
\hline 2 & Teaching Technique & 册 III & 8 & $9.41 \%$ \\
\hline 3 & Style and Strategy & HWH HWH & 20 & $23.52 \%$ \\
\hline 4 & CALL/Multimedia & HI & 6 & $7.05 \%$ \\
\hline 5 & Classroom management & 册 III & 8 & $9.41 \%$ \\
\hline 6 & Planning and course design & 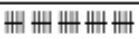 & 25 & $29.41 \%$ \\
\hline 7 & Personality factor & HI & 6 & $7.05 \%$ \\
\hline 8 & Linguistic factor & 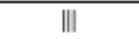 & 3 & $3.52 \%$ \\
\hline \multicolumn{3}{|c|}{ TOTAL } & 85 & \\
\hline
\end{tabular}


In the table above, it shows the total percentage of the trend on TEFL research in term on topic used by students in English education department across 2017. The highest topic that was chosen was Planning and course design (29.41\%), and followed by Style and Strategy $(23.52 \%) /$ The third one was Approach or Methodology (10.58\%), and followed by Teaching Technique and classroom management $(9.41 \%)$. CALL/Multimedia and personality factor were balance $(7.05 \%)$, and the lowest one was linguistic factor $(3.52 \%)$

Table 6.Trend on the research topic within the last 3 Years (2015-2017)

\begin{tabular}{|l|l|l|l|l|l|l|}
\hline No & Research topic & \multicolumn{2}{|l|}{ Years } & Frequency & Percentage \\
\cline { 3 - 5 } & & 2015 & 2016 & 2017 & \\
\hline 1 & $\begin{array}{l}\text { Approach or } \\
\text { Methodology }\end{array}$ & 5 & 3 & 9 & 17 & $10.05 \%$ \\
\hline 2 & $\begin{array}{l}\text { Teaching } \\
\text { Technique }\end{array}$ & 5 & 4 & 8 & 17 & $10.05 \%$ \\
\hline 3 & $\begin{array}{l}\text { Style and } \\
\text { Strategy }\end{array}$ & 13 & 9 & 20 & 42 & $24.85 \%$ \\
\hline 4 & $\begin{array}{l}\text { CALL } \\
\text { Multimedia }\end{array}$ & 4 & 4 & 6 & 14 & $8.24 \%$ \\
\hline 5 & $\begin{array}{l}\text { Classroom } \\
\text { management }\end{array}$ & 3 & 4 & 8 & 15 & $8.87 \%$ \\
\hline 6 & $\begin{array}{l}\text { Planning and } \\
\text { course degign }\end{array}$ & 8 & 9 & 25 & 42 & $24.85 \%$ \\
\hline 7 & $\begin{array}{l}\text { Personality } \\
\text { factor }\end{array}$ & 3 & 1 & 6 & 10 & $5.91 \%$ \\
\hline 8 & $\begin{array}{l}\text { Linguistic } \\
\text { factor }\end{array}$ & 5 & 4 & 3 & 12 & $7.10 \%$ \\
\hline
\end{tabular}

Based on Table 6, It is shown that the highest percentage of research topic in TEFL research was style or strategy and planning course design (24.85\%). The second highest was approach and methodology and teaching technique studies $(10.05 \%)$. The third was classroom management $(8.87 \%)$, next, followed by CALL/Multimedia (8.24\%), than followed by linguistic factor $(7.10 \%)$, and the lowest one was personality factor $(5.91 \%)$.

\section{b. The trend of TEFL research in term of target language skills among the theses of students in English Educational Program period 2015 to 2017.}

Table 7. Trend on target language skill in the year of 2015

\begin{tabular}{|c|c|c|c|c|}
\hline No & Target language skill & Tallies & Frequency & Percentage \\
\hline 1 & Listening & 1 & 1 & $2.17 \%$ \\
\hline 2 & Speaking & HWH & 12 & $26.08 \%$ \\
\hline 3 & Reading & $H \|$ & 8 & $17.39 \%$ \\
\hline 4 & Writing & 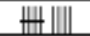 & 9 & $19.56 \%$ \\
\hline 5 & Grammar & III & 4 & $8.69 \%$ \\
\hline 6 & Vocabulary & 刺 & 5 & $10.86 \%$ \\
\hline 7 & Pronunciation & & 0 & 0 \\
\hline 8 & Integrated skill & HU & 7 & $15.21 \%$ \\
\hline \multicolumn{3}{|c|}{ TOTAL } & 46 & $100 \%$ \\
\hline
\end{tabular}

Based on Table 7, it is shown that the highest target language skill that was chosen was speaking (26.08\%), the second highest was writing (19.56\%), and the third was reading $(17.39 \%)$. The fourth one was integrated skill $(15.21 \%)$. Then, the fifth one was vocabulary $(10.86 \%)$. After that, it was followed by grammar $(8.69 \%)$. The lowest one was listening $(3.57 \%)$. In the other hand there is no research was conducted using pronunciation.

Table 8. Trend on target language skill in the year of 2016

\begin{tabular}{|c|c|c|c|c|}
\hline $\mathrm{N}_{0}$ & Target language skill & Tallies & Frequency & Percentage \\
\hline 1 & Listening & II & 2 & $5.26 \%$ \\
\hline 2 & Speaking & ||| & 4 & $10.52 \%$ \\
\hline 3 & Reading & 世山 & 9 & $23.68 \%$ \\
\hline 4 & Writing & $\mathrm{HI} \mid \mathrm{II|}$ & 9 & $23.68 \%$ \\
\hline 5 & Grammar & H & 5 & $13.15 \%$ \\
\hline 6 & Vocabulary & || & 3 & $7.89 \%$ \\
\hline 7 & Pronunciation & L & 1 & $2.63 \%$ \\
\hline 8 & Integrated skill & 再 & 5 & $13.15 \%$ \\
\hline \multicolumn{3}{|c|}{ TOTAL } & 38 & $100 \%$ \\
\hline
\end{tabular}

In 2016, reading and writing were the highest target language skill (23.68\%). The second highest was grammar and integrated $(13.15 \%)$, and the third was speaking and integrated skill (10.52\%). It was followed by vocabulary $(7.89 \%)$, and listening $(5.26 \%)$. Then, the lowest one was pronunciation $(2.63 \%)$.

Table 9. Trend on target language skill in 2017

\begin{tabular}{|c|c|c|c|c|}
\hline $\mathrm{N}_{0}$ & Target language skill & Tallies & Freguency & Percentage \\
\hline 1 & Listening & $\|$ & 2 & $2.35 \%$ \\
\hline 2 & Speaking & $\mathrm{HWH}$ & 16 & $18.82 \%$ \\
\hline 3 & Reading & $\mathrm{HWH}$ & 15 & $17.64 \%$ \\
\hline 4 & Writing & HWH & 15 & $17.64 \%$ \\
\hline 5 & Grammar & $H+$ & 11 & $12.94 \%$ \\
\hline 6 & Vocabulary & 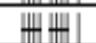 & 11 & $12.94 \%$ \\
\hline 7 & Pronunciation & & 0 & 0 \\
\hline 8 & Integrated skill & HWHIII & 14 & $16.47 \%$ \\
\hline \multicolumn{3}{|c|}{ TOTAL } & 85 & $100 \%$ \\
\hline
\end{tabular}

Speaking was the highest research topic conducted by students $(18.82 \%)$, and reading and writing were the second highest $(17.64 \%)$. The third one was integrated skill $(16.47 \%)$. It was followed by Grammar and vocabulary (12.94\%), and the lowest target language skill was listening $(2.35 \%)$. In the other hand, there was no research conducted using pronunciation. 
Table 10. Trend on the target language skill within the last 3 Years (2015-2017)

\begin{tabular}{|c|c|c|c|c|c|c|}
\hline \multirow[t]{2}{*}{ No } & \multirow{2}{*}{$\begin{array}{l}\text { Target } \\
\text { language skill }\end{array}$} & \multicolumn{3}{|c|}{ Years } & \multirow[t]{2}{*}{ Frequency } & \multirow[t]{2}{*}{ Percentage } \\
\hline & & 2015 & 2016 & 2017 & & \\
\hline 1 & Listening & 1 & 2 & 2 & 5 & $2.95 \%$ \\
\hline 2 & Speaking & 12 & 4 & 16 & 32 & $18.93 \%$ \\
\hline 3 & Reading & 8 & 9 & 15 & 32 & $18.93 \%$ \\
\hline 4 & Writing & 9 & 9 & 15 & 33 & $19.52 \%$ \\
\hline 5 & Grammar & 4 & 5 & 11 & 21 & $12.42 \%$ \\
\hline 6 & Vocabulary & 5 & 3 & 12 & 20 & $11.83 \%$ \\
\hline 7 & Pronunciation & 0 & 1 & 0 & 1 & $0.59 \%$ \\
\hline 8 & Integrated & 7 & 4 & 13 & 25 & $14.79 \%$ \\
\hline \multicolumn{2}{|c|}{ TOTAL } & 46 & 38 & 85 & 169 & $100 \%$ \\
\hline
\end{tabular}

Based on table, it was found that writing was the highest percentage of target language skill in TEFL (19.52\%). The second was speaking and reading $(18.93 \%)$. The third one was integrated skill $(14.79 \%)$. The fourth was grammar $(12.42 \%)$. Then, it was followed by vocabulary $(11.83 \%)$ and listening $(2.95 \%)$. The lowest target language skill was pronunciation $(0.59 \%)$.

\section{c. The trend of TEFL research in term of research method apply by the students of English Educational Program periode 2015 to 2017.}

Table 11. Trend on research method applied in 2015

\begin{tabular}{|c|c|c|c|c|}
\hline No & Research method & Tallies & Frequency & Percentage \\
\hline 1 & $\begin{array}{l}\text { Descriptive } \\
\text { qualitative }\end{array}$ & \#冊州 & 15 & $32.60 \%$ \\
\hline 2 & $\begin{array}{l}\text { Descriptive } \\
\text { quantitative }\end{array}$ & WH HW MI & 21 & $45.65 \%$ \\
\hline 3 & Experiment & $\mathrm{HL}$ & 6 & $13.04 \%$ \\
\hline 4 & Correlation & لII & 4 & $8.69 \%$ \\
\hline 5 & Comparative & & 0 & 0 \\
\hline 6 & R\&D & & 0 & 0 \\
\hline 7 & Action research & & 0 & 0 \\
\hline 9 & Content analysis & & 0 & 0 \\
\hline \multicolumn{3}{|c|}{ TOTAL } & 46 & $100 \%$ \\
\hline
\end{tabular}

Based on the result, descriptive quantitative was the highest research method conducted by students (45.65\%), descriptive qualitative was the second highest (32.60\%), and the third was experiment (13.04\%). The lowest research method was correlation $(8.69 \%)$. On the other hand, there was no research conducted using comparative, R \& D, action research and content analysis.
Table 12. Trend on research method applied in 2016

\begin{tabular}{|c|c|c|c|c|}
\hline No & Research method & Tallies & Frequency & Percentage \\
\hline 1 & Descriptive qualitative & HUIU & 9 & $23.68 \%$ \\
\hline 2 & Descriptive quantitative & H\#H州川 & 17 & $44.73 \%$ \\
\hline 3 & Experiment & H緼 & 11 & $28.94 \%$ \\
\hline 4 & Conrelation & 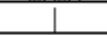 & 1 & $2.63 \%$ \\
\hline 5 & Comparative & & 0 & 0 \\
\hline 6 & R\&D & & 0 & 0 \\
\hline 7 & Action research & & 0 & 0 \\
\hline 8 & Content analygis & & 0 & 0 \\
\hline \multicolumn{3}{|c|}{ TOTAL } & 38 & $100 \%$ \\
\hline
\end{tabular}

Based on the analysis, the highest research method that was chosen was descriptive quantitative (44.73\%). It was followed experiment (28.94\%). The third one was descriptive qualitative $(23.68 \%)$, and the lowest research method was correlation $(2.63 \%)$. Besides, there was not some research conducted about comparative, $\mathrm{R} \& \mathrm{D}$, action research and content analysis.

Table 13. Trend on research method applied in 2017

\begin{tabular}{|c|c|c|c|c|}
\hline $\mathrm{N}_{0}$ & Research method & Tallies & Frequency & Percentage \\
\hline 1 & Descriptive qualitative & HIIII & 13 & $15.29 \%$ \\
\hline 2 & Descriptive & 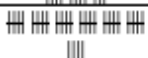 & 34 & $40.00 \%$ \\
\hline 3 & Experiment & 世世世緼 & 27 & $31.76 \%$ \\
\hline 4 & Correlation & HI & 5 & $5.88 \%$ \\
\hline 5 & Comparative & & 1 & $1.17 \%$ \\
\hline 6 & R\&D & & 2 & $2.35 \%$ \\
\hline 7 & Action research & & 2 & $2.35 \%$ \\
\hline 8 & Content analygis & & 2 & $2.35 \%$ \\
\hline \multicolumn{3}{|c|}{ TOT } & 85 & $100 \%$ \\
\hline
\end{tabular}

It was found that in 2017 the highest research method that was descriptive quantitative $(40.00 \%)$, the second highest was experiment $(31.76 \%)$, and the third was descriptive qualitative (15.29\%). Meanwhile, Correlation was the fourth $(5.88 \%)$, then it was followed by R \& D and action research and content analysis is the lowest research method $(2.35 \%)$.

Table 14. Trend on the research method applied within the last 3 Years (2015-2017)

\begin{tabular}{|l|l|l|l|l|l|l|}
\hline \multirow{2}{*}{ No } & \multirow{2}{*}{} & Research method & \multicolumn{2}{|l|}{ Years } & \multirow{2}{*}{ Frequency } & \multirow{2}{*}{ percentage } \\
\cline { 3 - 6 } & & $\mathbf{2 0 1 5}$ & $\mathbf{2 0 1 6}$ & $\mathbf{2 0 1 7}$ & & \\
\hline 1 & Descriptive qualitative & 15 & 9 & 13 & 37 & $21.89 \%$ \\
\hline 2 & Descriptive quantitative & 21 & 16 & 34 & 71 & $42.01 \%$ \\
\hline 3 & Experiment & 6 & 11 & 27 & 44 & $26.03 \%$ \\
\hline 4 & Comelation & 4 & 1 & 5 & 10 & $5.91 \%$ \\
\hline 5 & Comparative & & & 1 & 1 & $0.59 \%$ \\
\hline 6 & R\&D & & & 2 & 2 & $1.18 \%$ \\
\hline 7 & Action research & & & 2 & 2 & $1.18 \%$ \\
\hline 8 & Content analyais & & & 2 & 2 & $1.18 \%$ \\
\hline \multicolumn{2}{|c|}{ TOTAL } & 46 & 38 & 85 & 169 & $100 \%$ \\
\hline
\end{tabular}

The table above presents the total percentage of the trend on TEFL research in term on research method used by students in English education 
department from the year 2015 until 2017. It was found that descriptive quantitative was the highest percentage of research method in TEFL research $(42.01 \%)$. The second was experiment (26.03\%). The third was descriptive qualitative $(21.89 \%)$. Next, it was followed by correlation $(5.91 \%), \mathrm{R} \& \mathrm{D}$, action research and content analysis $(1.18 \%)$. Meanwhile, the lowest was comparative $(0,59 \%)$.

\section{CONCLUSION}

Research topics were analyzed under eight subcategories: approach or methodology, teaching technique, style and strategies, CALL/Multimedia, classroom management, planning and course design, personality factor, linguistic factor. Style or strategy and planning course design were the trend research topic in TEFL research $(24.85 \%)$ within the last three years 2015 -2017. The second highest was approach and methodology and teaching technique studies $(10.05 \%)$. The third was classroom management (8.87\%), next, followed by CALL/Multimedia $(8.24 \%)$, than followed by linguistic factor (7.10\%), and the lowest chosen topic was personality factor $(5.91 \%)$

Target language skill was analyzed under eight subcategories: listening, speaking, reading, writing, grammar, vocabulary, pronunciation and integrated skill. Researcher found that writing was the highest percentage of target language skill in TEFL research it was $(19.52 \%)$. The second one was speaking and reading (18.93\%). The third one was integrated skill $(14.79 \%)$. The fourth was grammar $(12.42 \%)$ followed by vocabulary $(11.83 \%)$, listening $(2.95 \%)$, and the lowest target language skill was pronunciation $(0.59 \%)$.

Research methods were also analyzed under eight subcategories: descriptive qualitative, descriptive quantitative, experiment, correlation, comparative, R \& $\mathrm{D}$, action research and content analysis. It was found that descriptive quantitative was the highest percentage of research method in TEFL research $(42.01 \%)$. The second one was experimental research (26.03\%). The third was descriptive qualitative (21.89\%) followed by correlation $(5.91 \%), \mathrm{R} \& \mathrm{D}$, action research and content analysis $(1.18 \%)$, and the lowest one was comparative $(0,59 \%)$.

\section{REFERENCES}

[1] Nunan.Research Methods in Language Learning: Excerpt. Cambridge: Cambridge University Press, 2012
[2] D. Brown. Principles of Language Learning and Teaching. New York: Pearson Longman, 2007.

[3] Donal Ary. Introductions to Research in Education, (Canada: Cengage Learning), 2010.

[4] J.W.Creswell. Educational Research, (New Jersey: Upper Saddle River, 2002.

[5] L.Cohen. Research Methods in Education, Taylor \& Fancis e - Library, 2005.

[6] I. Erna, S. Arina, Research Trends of EFL Students in English Education Program: A 2005-2015 Survey, Samarinda:: Journal of Dinamika Ilmu, 2017.

[7] Ma \& Kim. Current Research Trends of English Education in Domestic and International journals, Korea:Chonnam National University, 2014

[8] L.R.Gay. Educational Research, Singapore: Merill Publishing Company, 1990

[9] S. Arikunto, Prosedur penelitian suatu Pendekatan Praktik. Jakarta: PT RinekaCipta, 2006 